\title{
Tradução transcultural no filme "O": Othelo ontem e hoje
}

Ádria Graziele Pinto; Graduanda em Letras, Universidade de Santa Cruz do Sul - UNISC, Santa Cruz do Sul, RS; Email: <adria.graziele@hotmail.com>.

Dr. Ana Cláudia Munari Domingos; Professora do Mestrado em Letras, Universidade de Santa Cruz do Sul - UNISC, Santa Cruz do Sul, RS; Email: <anacmunari@unisc.br>.

\section{Resumo}

0 artigo discute a relação intersemiótica entre o filme 0 , dirigido por Tim Blake Nelson e escrito por Brad Kaaya (2001), e a obra Othelo, The Moor of Venice, de Shakespeare, contemplando o conceito de tradução transcultural a partir dos estudos de Thaïs Flores Nogueira Diniz. O filme analisado rompe com 0 ideal utópico de fidelidade e, consequentemente, faz com que a transposição audiovisual seja vista como uma criação independente e legítima. Defendendo uma concepção de adaptação que ultrapassa a mera duplicação e considerando os diálogos possíveis entre os signos verbais do drama e o cinema, a análise é centrada nos protagonistas - Othello e Odin - e salienta as inúmeras particularidades correspondentes a cada personagem, a partir da leitura de estudiosos como Jan Kott e Martin Lings. A figuração do herói do teatro elisabetano é contrastada com a do herói contemporâneo apresentado pelo filme, sobretudo na permanência/distorção das questões de ordem existencial das personagens e seu contexto social. A produção $O$ transfere a história clássica para 0 contexto contemporâneo, adaptando elementos referenciais e apostando no dialogismo das obras, fazendo com que o tripé "traiçãociúme-vingança" seja perpetuado e dirigindo-se ao espectador hodierno.

Palavras-chave: William Shakespeare, Othelo, 0 , tradução transcultural, tradução intersemiótica, figuração do herói.

\section{Duas artes}

A necessidade de exteriorizar sua importância no mundo e, consequentemente, posicionar-se como sujeito social, sempre se fez presente na vida do homem. Motivado por diversas circunstâncias, o ser humano compreendeu, desde sua origem, que era possível comunicar-se utilizando o corpo como ferramenta. 
O Teatro, atualmente palco de dramatizações daquelas mesmas histórias mitológicas até as mais hodiernas formas de representar as ações do homem, possuía, em sua origem, um caráter ritualístico. Acredita-se que suas primeiras manifestações possam ser remontadas a partir das primeiras sociedades primitivas, que utilizavam as danças imitativas como forma de entender e, simbolicamente, controlar fatos relacionados à sobrevivência, muitas vezes com a intenção de assegurar poderes sobre a natureza.

Etimologicamente, a origem da palavra teatro remete ao verbo grego theastai, aproximando o seu sentido ao "ver", "contemplar". Inicialmente, o termo designava o local onde aconteciam espetáculos para, mais tarde, indicar qualquer tipo de espetáculo. O sentido que a palavra desperta hoje em nós definiu-se no séc. XVII, justamente a partir do domínio de Shakespeare no drama inglês.

A evolução do drama e os esforços para se reproduzir a realidade por meios artificiais, como a pintura figurativa e a fotografia, por exemplo, contribuíram para o surgimento do que chamados de sétima arte, o cinema. Em comparação com as outras artes que tentavam exprimir um instantâneo da realidade, a cinematografia contava com um elemento revolucionador: o movimento - fundamental para produzir a impressão da realidade. Posterior à fotografia, tendo sua criação marcada pelo ano de 1895, na França, o cinema é fruto de investigações acerca dos fundamentos da ciência óptica. Reúne as formas de linguagem que podem ser expressas pela arte: som, imagem, movimento, cor, volume, palavra.

A união da linguagem audiovisual e da verbal, proporcionada pelo cinema, fez com que a indústria cinematográfica se consolidasse como uma das formas de artes mais amplas e democráticas, capaz de alcançar um público heterogêneo. Como afirma Walter Benjamin, no ensaio A obra de arte na era de sua reprodutibilidade técnica, "[...] a reprodução técnica pode colocar a cópia do original em situações impossíveis para 
o próprio original. Ela pode, principalmente, aproximar do indíviduo a obra [...]". Esse sistema de cópias permitiu uma enorme expansão do mercado cinematográfico, que aliado à televisão, mídia que surgiu algumas décadas depois, concretiza-se como uma mercadoria abstrata e perecível, consumida em massa. Sendo o meio televisivo um dos coletivos mais baratos e de maior circulação nos nichos sociais contemporâneos, seu papel na propagação de filmes concretiza certo ideal de democracia, pois é a partir da televisão que o filme chega a pequenas cidades e lugares desprovidos de um cinema.

\section{Diálogos entre linguagens}

O cinema e a literatura ${ }^{1}$ coexistem desde o surgimento do primeiro, seja na interdependência dos dois sistemas ou na influência de um sobre o outro. Os diálogos que provieram da coexistência entre essas duas artes acabaram desencadeando vários conceitos acerca da palavra adaptação, que, em seu sentido mais amplo, é entendido como um processo de procura de equivalência entre dois sistemas distintos, que usam seus próprios meios de representação. O romancista dispõe unicamente da linguagem verbal como meio de expressão, já o cineasta além de apropriar-se da linguagem verbal, dispõe de outros meios para a concretização do texto, como a música e a visualidade. Aspectos como as imagens em movimento, por exemplo, que na literatura são apenas sugeridos, apresentamse de forma concreta no discurso cinematográfico. Escrita e imagem não comunicam de forma independente quando presentes em um mesmo sistema, assim, não podemos pressupor uma separação entre os signos visuais e verbais no

1 Incluímos aqui o drama, porque trataremos do texto de Shakespeare em seu aspecto verbal e não a encenação. 
cinema, pois, considerados no âmbito da representação, eles dialogam e interagem entre si.

O conceito de tradução vem sofrendo fortes transformações. Além da relativização da noção de origem, e do fim da busca pela fidelidade na transposição, as ideias sobre tradução passam a enfatizar que os textos devem ser considerados signos um do outro. A semelhança entre uma obra e outra pode ocorrer de forma sutil, desde que permita uma referência mútua entre os textos, muitas vezes dada pelo leitor ou, ainda, inexistente, porque não percebida. Essa equivalência pode estar limitada apenas a inter-relações evidentes que justifiquem a afirmação dos textos como signos um do outro. A conceituação acerca do termo tradução mostra-se relevante para que determinada obra possa ser considerada uma adaptação de outra.

Durante muito tempo a tradução foi duramente avaliada como "certa" ou "errada". Por ser encarada como um produto, era estudada e criticada segundo critérios tradicionais a respeito da concepção de fidelidade. Esses parâmetros rígidos sofreram alterações, o que conferiu um status de transformação às traduções. A partir dessa visão abrangente, foi possível encarar o estudo das inter-relações entre a literatura, o teatro e outros gêneros artísticos como formas de traduções, e mesmo como resultado de leituras particulares de hipotextos (Diniz, 2005).

Concomitante à transposição intertextual, que é a presença de um texto em outro, está presente a questão transcultural quando uma obra ambientada em um determinado espaço/tempo é traduzida para outro contexto que, por sua vez, é influenciado pela sua própria cultura. Em Literatura e cinema: da semiótica à tradução cultural, Thaïs Flores Nogueira Diniz afirma:

Os signos, quando combinados, podem criar estruturas significantes em um outro nível, o conotativo, implícito. A combinação, produzida em determinadas circunstâncias, resulta em significados imprevisíveis, construídos pelo leitor/espectador, que se encontra em outras 
circunstâncias, em outro momento, em outra cultura. Isto faz com que toda tradução seja transcultural (1999: 72).

No filme $O$, o contexto sócio-histórico da narrativa - a esfera cultural - é evidentemente transformado em relação ao original Othelo. Dessa forma, pode-se afirmá-la como um exemplo de tradução transcultural, já que o filme recria a fábula em outra época e espaço, criando uma espécie de dialogismo com a obra original. Ao romper com o ideal utópico de fidelidade, o filme comunica-se com a peça teatral através de referências intertextuais.

A adaptação cinematográfica ultrapassa a linguagem das palavras, instalando-se, principalmente, nas imagens e sons. É através de seu exame que podemos observar a presença de uma das passagens mais famosas do drama, pronunciada pelo alferes lago, que define o ciúme como um "monstro dos olhos verdes ${ }^{2 \prime}$.

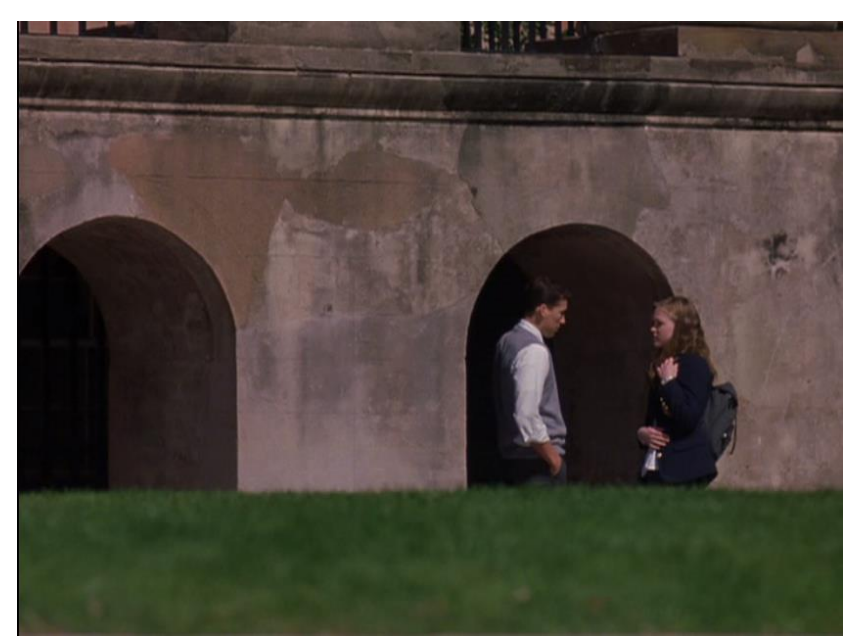

Fig. 1: Na obra audiovisual, a referência à passagem da peça é exposta através do uso da cor verde nas cenas que provocariam ciúme de Odin.

2 Todas as passagens referentes à obra Othelo foram retiradas da tradução para o português: SHAKESPEARE, W. Otelo. Trad. Beatris Viégas-Faria. Porto Alegre: LP\&M, 2012. 


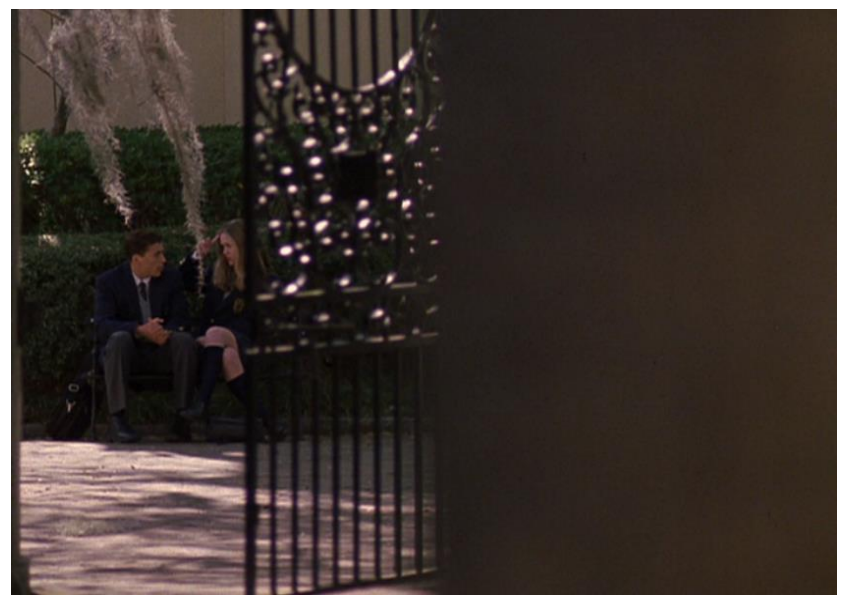

Fig 2: Nesta cena podemos ver o verde (referindo-se à passagem de lago) e o salgueiro (símbolo da morte de Dêsdemona).

Outras inferências são apresentadas de forma sutil ao longo da trama. No início do filme, enquanto acontece a narração, podemos ouvir, como música de fundo, a ária de Desdêmona, final da ópera Othelo, de Verdi. A canção, "Willow Song", é a mesma que Desdêmona canta na peça, momentos antes de ser morta pelas mãos de seu marido. A imagem do salgueiro perdura ao longo do filme, precedendo as cenas que remetem ao ciúme que, concomitante à estrofe "[...] salgueiro, meu verde salgueiro" presente na canção, reforça a unificação da imagem da árvore ao sentimento que é despertado no mouro. E, assim, são referências diretas à obra de Shakespeare.

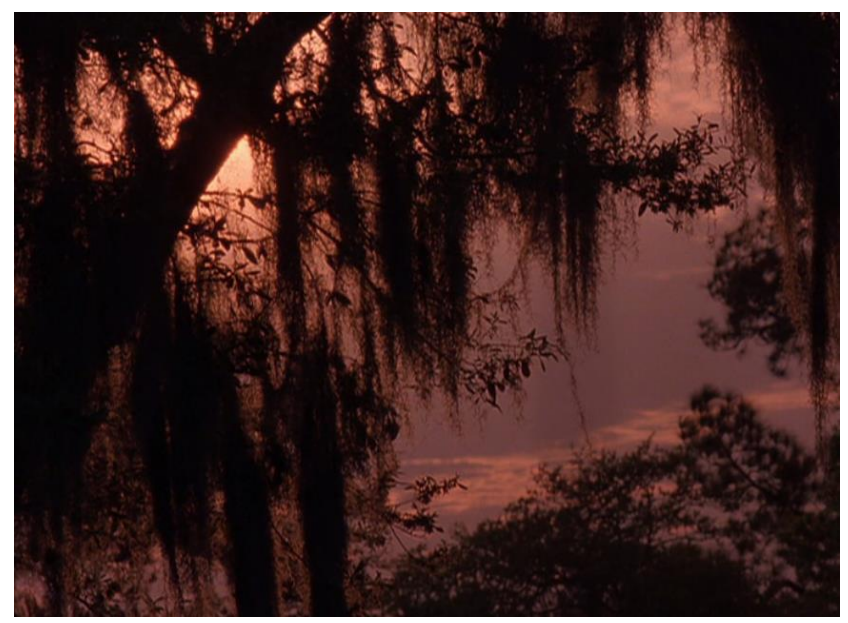

Fig. 3: Uma das imagens do salgueiro. 


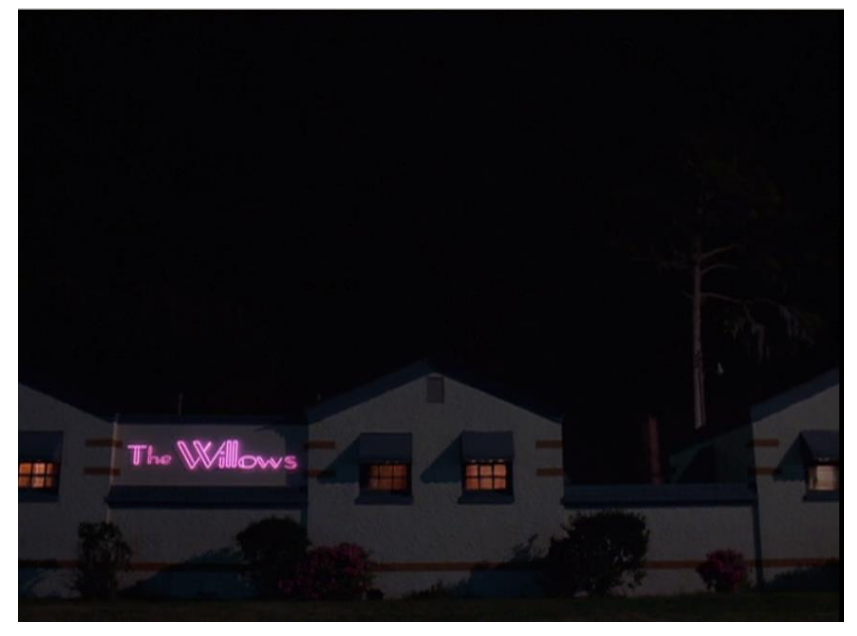

Fig. 4: Outra referência ao salgueiro. Neste caso, o nome do motel, The willows - salgueiro, em inglês - precede uma cena de violência contra Desi. Também é o único espaço para o qual a cena se desloca além da cidade onde se localiza a escola, representando os atos em que, no drama de Shakespeare, os acontecimentos se dão em Chipre.

A tragédia de Shakespeare, cuja centralidade está no ciúme e na disputa pelo poder, já é uma adaptação, pois se baseia no romance de Cinthio. Como outros dramaturgos, Shakespeare voltou-se para autores antigos, usando suas obras como base para suas peças e desenvolvendo aspectos que julgava pertinentes para seus dramas. Esta observação não desmerece a capacidade de criação de Shakespeare, pois Othelo - como a adaptação fílmica $O$ - se sustenta, apesar da inspiração, como uma obra autêntica, composta por personagens com características próprias, que transcendem o original.

$\mathrm{Na}$ adaptação audiovisual, a busca pela autoria e pela atualização cultural se consolida através de muitas referências, sobretudo imagéticas. Podemos observar o uso da combinação azul, vermelho e branco, que, automaticamente, resgata a imagem das cores da bandeira norte-americana. Essa combinação está presente, essencialmente, no uniforme dos jogadores e consolida um aspecto importante do drama, que é o contexto da disputa entre exércitos, reforçando o sentimento de nação. 


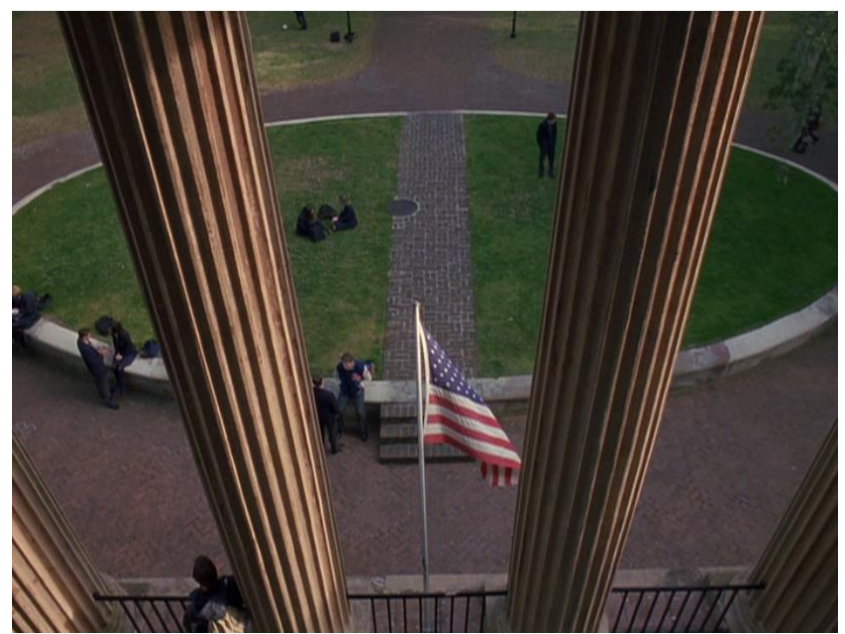

Fig. 5: A bandeira, exibida estrategicamente, enfatiza o processo de transculturalidade.

Shakespeare consolidou uma dimensão clássica a um sentimento corriqueiro, tornando Otelho o símbolo do ciúme desmedido e irracional. Tendo como pano de fundo as batalhas marítimas de Chipre, somos apresentados a um general negro inserido em um mundo de brancos. Nas duas obras (dramática e audiovisual), o drama é consequência de várias disputas entre os personagens, porém, na transposição fílmica, os cenários e motivações foram adaptados a outro universo.

Para ajustar-se ao contexto contemporâneo em que se situa a história da adaptação audiovisual, alguns elementos tiveram de sofrer alterações para corresponder aos sentidos dados pela obra de Shakespeare. O tripé "disputa-inveja-ciúme”, no filme, continua sendo a grande centralidade da obra, movimentando o enredo, e, aliado a paralelos evidentes, como a semelhança entre os nomes dos personagens, estabelece a referência com a peça inglesa. A mudança é explicitada primeiramente no nome do filme. A letra "O", que nomeia a obra, além de ser uma referência clara ao nome do protagonista Odin (nome de influência mitológica, deus nórdico da sabedoria, guerra e morte), funciona como uma ponte dialógica entre a criação cinematográfica e a obra de partida. No filme, somos 
transportados para outro ambiente onde ocorre o drama. Em vez de um exército que luta contra os turcos, deparamo-nos com um time de basquete. No lugar das batalhas marítimas, temos as partidas contra times adversários. E, para substituir Othelo, nos é apresentado Odin que, além de ser o único negro da escola, é o capitão do time. Colocar Odin em uma escola de brancos - uma instituição conservadora do subúrbio estadunidense - é providencial, já que um jogador negro em um time de basquete não seria singular. Essa foi a maneira encontrada para aproximar os contextos de Odin e Othelo, já que este é um negro entre brancos, caracterizando-se como uma adaptação transcultural que tem por princípio concretizar o mesmo sentido da obra anterior.

A grande motivação da peça é a inveja causada em lago ao saber que Cassio foi promovido a tenente de Othelo. Acreditando ser desmerecida essa promoção, lago inicia seu plano de vingança contra o mouro, levando-o a acreditar que Desdêmona o está traindo com seu amigo e tenente. No filme, a motivação de Hugo, personagem que corresponde a lago, é reforçada pela relação áspera que o personagem mantém com seu pai e treinador que, por outro lado, distingue Odin como seu preferido. Este detalhe torna-se imprescindível à dramaticidade do roteiro. Logo nos primeiros cinco minutos do filme nos deparamos com a seguinte frase, dita pelo personagem Duke, referindo-se a Odin: 


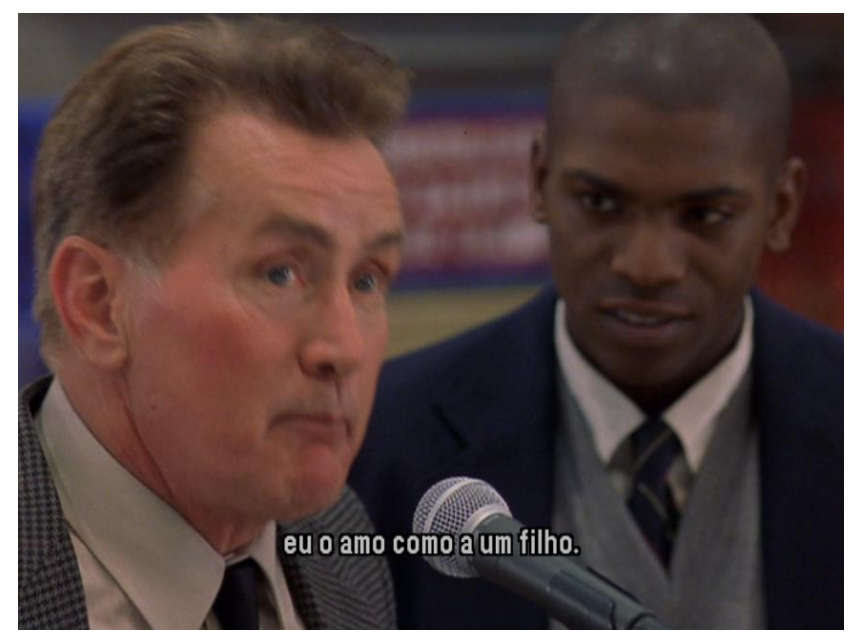

Fig. 6: Uma das motivações de Hugo

A disputa não se limita apenas à questão da afeição paterna. A competição presente na obra do dramaturgo inglês é representada, na adaptação, através de uma premiação em que Odin ganha o troféu de "O mais valioso jogador" do time. Se em Othello o mouro promove Cassio a seu tenente, elevando-o a um posto mais significante, no filme, Odin divide o prêmio de melhor jogador com Mike, intensificando o sentimento de inveja em Hugo que, assim como lago, acha desmerecido o destaque e atenção dados a Mike. Neste caso, como não há hierarquisas no basquete, foi necessário criar uma situação de favorecimento/desigualdade.

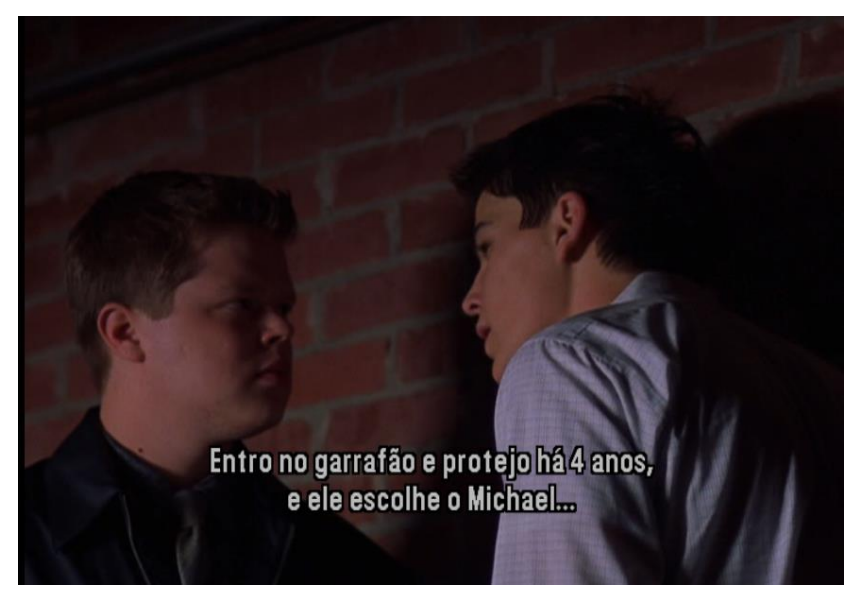

Fig. 7: A passagem acima estabelece diálogo com a obra original, reforçando o ideal de lago/Hugo sobre o verdadeiro mérito de Cássio/Mike. 
Essa e outras recriações comprovam o caráter original que a transposição fílmica apresenta, ao mesmo tempo em que mostra que é esse tipo de transformação que pode aproximar a recepção de ambas. O roteiro de Brad Kaaya confere ao personagem Hugo uma nova identidade, com certa independência de sua fonte, mas são essas características que aproximam as figurações de Hugo e lago entre si. Como reforça o crítico literário norte-americano Harold Bloom, "Shakespeare não confere antepassados e antecedentes a lago. Podemos apenas inferir sobre o relacionamento prévio entre o alferes e seu capitão" (Bloom, 2000: 546). Já no filme nos deparamos com uma visão mais intimista a respeito da vida pessoal de Hugo e do relacionamento distante com seu pai e treinador, dados que preenchem as lacunas da obra de Shakespeare, sem corromper seu sentido.

Os nomes dos personagens também sofreram alterações: além de Othello passar a ser representado por Odin e o vilão lago receber o nome de Hugo, Desdêmona é substituído por Desi, Michael Cassio (ou Cassio, como é chamado a maior parte do tempo na peça) passa a ser chamado de Mike, Emília - esposa e cúmplice de lago/Hugo - é chamada de Emily e, por último, o Doge de Veneza, que no idioma original é chamado de Duke of Venice, no filme passa a ser nomeado apenas como Duke, que corresponde à figura do treinador do time de basquete.

As adaptações transcendem os nomes dos personagens e instalam-se, também, na ordem hierárquico-social. Ambientado em um espaço escolar em que as competições de basquete são representativas na valoração das instituições, a figuração do técnico do time, Duke, supera a importância da figura do diretor da escola, fazendo com que a relevância do personagem (que em uma situação real, fora do contexto esportivo apresentado pelo filme, não teria o mesmo peso) remonte à altivez do Doge na peça original. O mesmo acontece com Desi e Emily. Na peça original, Emília é a subordinada de 
Desdêmona. No filme, Desi e Emily pertencem ao mesmo plano, já que ambas são estudantes e Emily é colega de quarto e melhor amiga de Desi, o que destoa do contexto de senhora/serviçal do drama inglês. Assim, o que Emily inveja é o relacionamento romântico que sua melhor amiga mantém com Odin, querendo para si o mesmo tipo de amor (que ela não possui com seu namorado, Hugo).

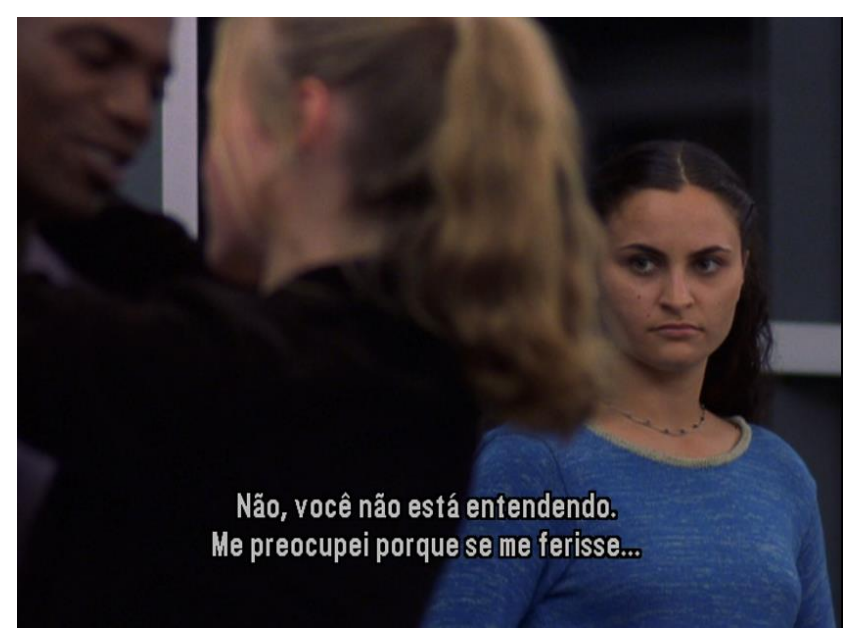

Fig 8: O diretor evidencia, através do foco em Emily e do halo desfocado no casal em primeiro plano, o sentimento de inveja que é alimentado pela amiga de Desi.

A tradução intersemiótica entre o teatro e o cinema é um fenômeno complexo principalmente pela incapacidade de se estabelecer uma sistematização satisfatória entre os signos, porque, apesar de distintos, eles se sobrepõem e se misturam. O material de expressão do sistema cinematográfico é constituído de palavras, imagens em movimento e sons, distinguindo-se pelas possibilidades que oferece de criar significado através de técnicas específicas (angulação, fragmentação das imagens, superposição, etc.) (Diniz, 1999).

Quando uma obra é transportada do teatro para o cinema, alguns elementos que pertencem exclusivamente ao teatro são substituídos por outros especificamente cinematográficos. No teatro, contamos com uma atuação única. As várias encenações de uma mesma peça nunca são exatamente iguais, assim como a atuação nunca é a mesma, há sempre 
diferenças na performance, decorrentes desde o estado de espírito dos atores, diferenças nos movimentos corporais até falhas e incidentes. $O$ intérprete em um filme não representa diante de uma plateia - e, portanto, não está suscetível a suas reações ou a incidentes -, mas sim diante de uma câmera e conta com um dos maiores recursos do cinema: a edição. Além disso, sua atuação fica depois cristalizada, não importando as várias sessões da obra. O filme de Tim Blake Nelson, roteirizado por Brad Kaaya, explora de forma primorosa os recursos dos quais dispõe o cinema. No filme $O$, podemos observar a conversão de uma narrativa literária em uma obra audiovisual que erige referências e busca concretizar sentidos próximos à obra que adapta através de sua própria linguagem, extrapolando o verbal.

Uma das grandes dessemelhanças é encontrada na adaptação do ciúme. Em sua peça, Shakespeare (2012) faz com que a intriga seja criada pela incitação verbal entre lago e Cassio, movimentando-a durante a história. Os personagens rumam à queda a partir de uma pequena dúvida implantada de forma aparentemente sutil, mas engendrada verbalmente, em Othello. É possível apontar para o momento em que lago inicia seu plano diabólico:

\footnotetext{
IAGO - Meu nobre senhor... OTHELO - O que dizes, lago?

IAGO - Miguel Cássio, quando o senhor cortejava esta que agora é sua esposa, ele sabia de seu amor por ela? OTHELO - Sabia, desde o primeiro instante. Por que perguntas?

IAGO - Para a mera satisfação da curiosidade de meus pensamentos. Não é por mal. (III, iii, 82-83)
}

O excerto acima é um exemplo de como lago brinca, simultaneamente, com todos os personagens da peça. Sua maneira maldosa de agir pode ser comparada a uma teia de aranha, onde um fato se entrelaça em outro. Antes de plantar a dúvida em Othello, o alferes já havia aproximado Cássio de Desdêmona, para que sua inquietação tivesse algum fundamento. 
No filme, essa inquietação e esse jogo de intriga se dão principalmente de forma visual. Hugo, assim como lago, planta sutilmente a dúvida em Odin, mas apenas como forma de iniciar o seu plano contra o colega de time. A manipulação discursiva, presente na peça, administrada pelo alferes, aparece de forma mais tênue na adaptação cinematográfica. É através do recurso imagético, característica principal do cinema, que acompanhamos a ruína do protagonista.

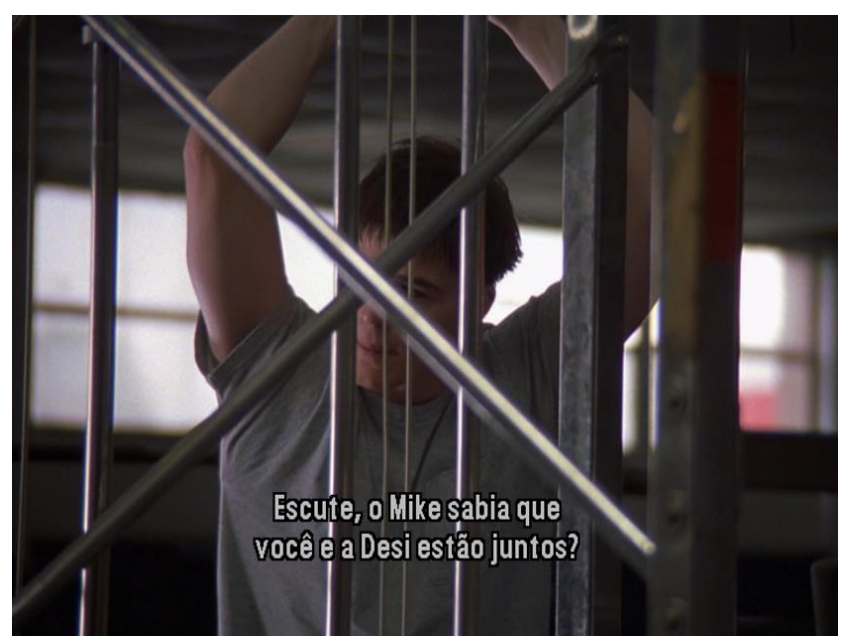

Fig. 9: O momento em que Hugo indaga Odin a respeito da proximidade entre Desi e Mike.

A fotografia, os planos e ângulos das imagens dessa cena que se passa em uma academia, durante uma série de exercícios que é cumprida por todos os jogadores do time -, exibe uma visão sugestiva dos equipamentos. Utilizando-se de planos médios e próximos em vários ângulos, o diretor produz uma cena íntima, fazendo com que o equipamento pareça barras de uma cela, como se Hugo fosse aprisionando Odin em seu plano. A academia representa como que um mecanismo, a máquina da intriga que começa a funcionar.

Alguns elementos, apesar da possibilidade de adaptação, foram mantidos na transposição americana. Essas particularidades concretizam-se como filetes de fidelidade para com o hipotexto. Podemos citar duas situações que sobreviveram à contemporaneidade da adaptação: o lenço e o modo como Desi foi morta. 
O lenço aparece no filme na mesma sequência (considerando que a adaptação segue a mesma cronologia da obra na qual se inspira) em que é introduzido na peça teatral. Assim como no drama de Shakespeare, somos informados, pelo próprio Odin, que o lenço seria uma peça estimada por ter pertencido à sua bisavó. Carregado de simbologia, o lenço cumpre o papel que Ihe é designado: engatilha o sentimento de certeza em Odin/Othelo a respeito da traição de Desi/Desdêmona ao mesmo tempo que proporciona à Emily/Emília uma chance de aproximação com Hugo/lago.

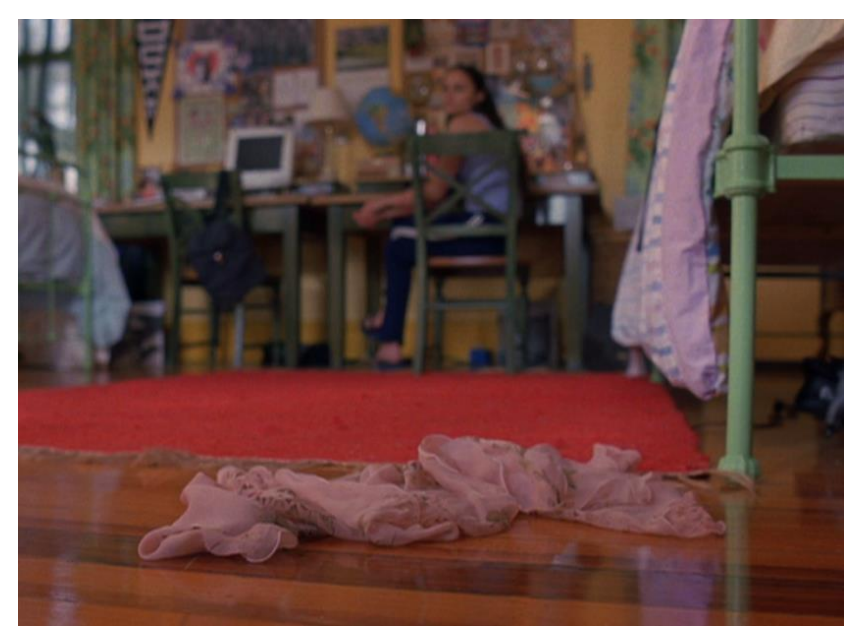

Fig. 9: Momento em que Emily decide roubar o lenço de Desi.

A morte de Desi também pode ser encarada como uma relação de diálogo com a obra inspiradora. Na cena em questão, Desi encontra-se em seu quarto, deitada em sua cama que, ao contrário do que ocorre na peça, não carrega nenhuma simbologia ou relevância para a criação da cena trágica, visto que em Othelo Desdêmona é morta na mesma cama onde passou sua primeira noite com o mouro, lugar da união entre alma e espírito destes amantes que são um o complemento do outro (Lings, 2004: 107-9). Mesmo não exercendo a função que cumpre na peça, é a cama que recebe o corpo inanimado de Desi. Assim como o episódio do lenço, as características originais nas quais ocorrem a morte de Desdêmona são preservadas. Odin, assim como Othelo, sufoca sua namorada até a morte, forma que já foi substituída em uma encenação de 1792 por ser muito primitiva (Kot, 2003: 104) 
A manutenção desses elementos no filme sem a adaptação ao contexto hodierno,acaba por inserir certa incoerência para o espectador. Sem confirmação da traição de Desi e sem apresentar quaisquer outros indícios de violência ou descontrole, Odin resolve a questão de uma maneira inverossímil naquele universo em que ele é admirado e importante em seu grupo, colocando por terra tudo aquilo pelo qual tinha se empenhado, sem refletir sobre as consequências que, na sociedade contemporânea, são diferentes daquele contexto em que a mulher está hierarquicamente abaixo do homem. Do mesmo modo, tanto o gesto decidido e rápido de Odin, sufocando sua amada, como a passividade de Desdêmona, que sequer pede socorro, não parecem refletir a passionalidade característica de uma tragédia moderna. Para o espectador que espera acusações, briga e violência dos dramas contemporâneos, a morte silenciosa de Desdêmona transforma realmente a história em uma tragédia, cujo significado é compreendido, por leitores de todos os tempos, pela hamartia, que aqui também se concretiza, mas a forma como se realiza não corresponde ao contexto cultural em que se insere. Da mesma maneira, o suicídio de Odin por um tiro no peito e não na cabeça ou na boca. No entanto, como sinaliza Kott (2003, p. 107), o palco de Shakespeare é o lugar em "que o mundo sai dos eixos, que o caos retorna e a própria ordem da natureza é ameaçada".

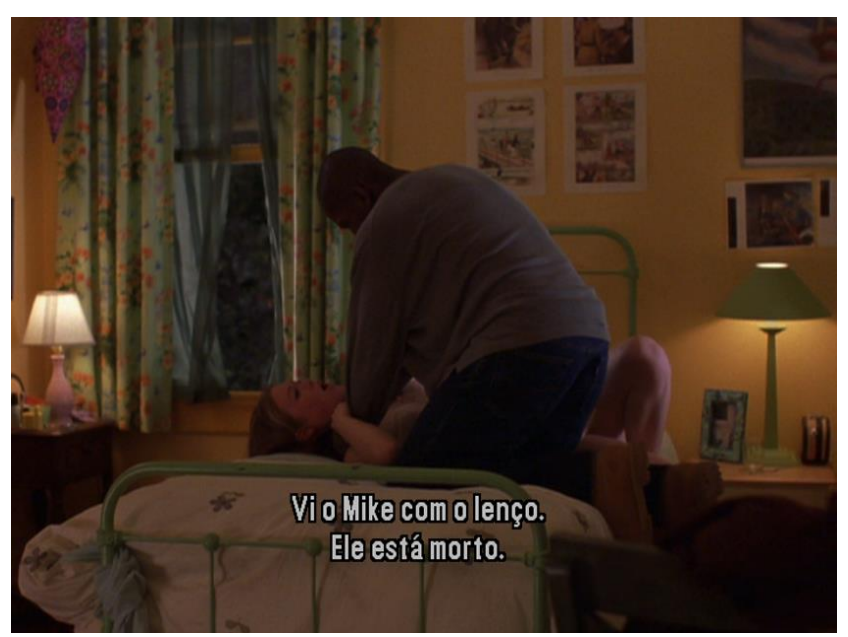

Fig. 10: Seguindo o padrão do hipotexto, Odin sufoca sua namorada. 


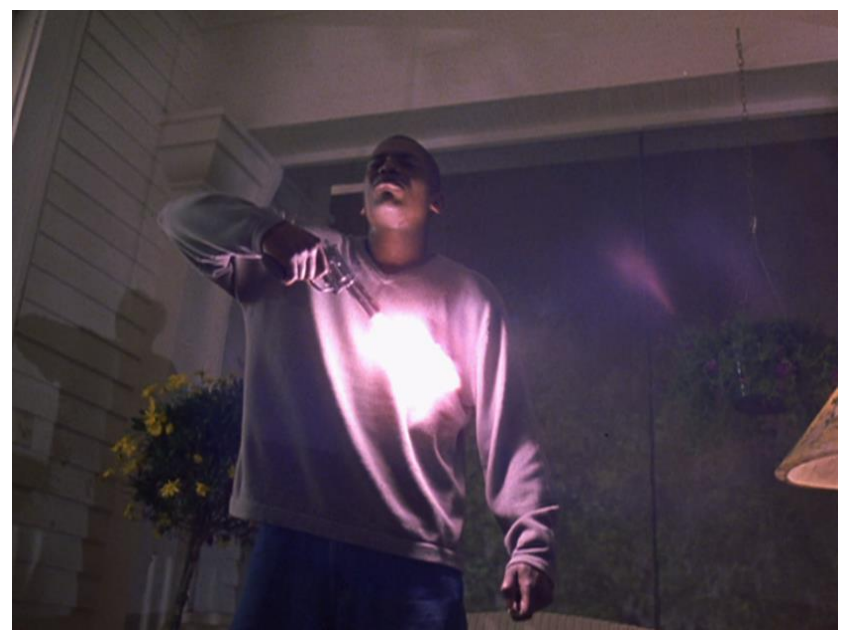

Fig. 11: Assim como Othelo, Odin comete suicídio.

\section{Uma história para sempre}

A figura de um vilão clássico se faz necessária em uma esfera na qual o herói é enganado e manipulado pelo antagonista sem motivos que não apenas os pecados do próprio vilão, como a ambição, a inveja. $\mathrm{O}$ mundo em que Odin consente com o assassinato de Mike e concorda em matar sua própria namorada precisa de uma figura como a de Hugo para servir de impulso ao erro do herói, transferindo a responsabilidade de tantas mortes para o vilão e, assim, transformando o herói trágico em vítima dessa sociedade. No fim, Odin passa a ser uma vítima da personalidade esquizofrênica de Hugo que, no entanto, tem seu comportamento justificado no seio familiar, tornando-se digno de pena apesar da vilania e afastando-se um pouco da figuração de lago, "de longe o mais infame dos vilões de Shakespeare" (LINGS, 2004: 108), uma espécie de demônio que age para tumultuar os mortais.

A transposição fílmica eleva as características que contribuem na consolidação de Othelo como uma das tragédias mais memoráveis de Shakespeare, acrescentando aspectos exclusivos da cultura contemporânea ao transportar a história para um cenário de fácil reconhecimento e identificação. Por se 
tratar de uma adaptação americana, cuja cultura é mundialmente conhecida justamente através do cinema, alguns aspectos reforçam esse possível reconhecimento no espectador, dando ao filme um caráter mais verossímil.

A figura de Odin estampa a imagem do herói moderno que, despido de preocupações a respeito de sua reputação ou honra, admite ter sido enganado, reconhecendo sua impotência diante de Hugo. Sua morte aproxima a audiência de sua realidade (considerando os inúmeros casos de tiroteios ocorridos em instituições americanas), causando um estranho reconhecimento acerca da perturbação decorrente desse tipo de situação, fazendo com que a tradução transcultural cumpra o seu papel diante do público receptor.

\section{Referências}

Benjamin, W. A obra de arte na era de sua reprodutibilidade técnica. Disponível em: http://www.mariosantiago.net/Textos\%20em\%20PDF/A\%20obra\%20d e\%20arte\%20na\%20era\%20da\%20sua\%20reprodutibilidade\%20t\%C 3\%A9cnica.pdf. Acesso em: 13 dez. 2014

Bloom, H. (2000). Shakespeare: a invenção do humano. Rio de Janeiro: Objetiva.

Diniz, T. F. N. (2005) Literatura e cinema: tradução, hipertextualidade, reciclagem. Belo Horizonte: Faculdade de Letras da UFMG. . (1999). Literatura e cinema: da semiótica à tradução. Ouro Preto: UFOP.

Kaaya, B. \& Nelson, T. B. O. (2001). [Filme-vídeo]. Produção de Brad Kaaya, direção de Tim Blake Nelson. Imagem Filmes. DVD, 95 min. color. son.

Kott, J. (2004). Shakespeare nosso contemporâneo. São Paulo: Polar Editorial \& Comercial.

Lings, M. (2004). A arte sagrada de Shakespeare. São Paulo: Polar Editorial \& Comercial. 
Shakespeare, W. (2012). Otelo. Trad. Beatris Viégas-Faria. Porto Alegre: LP\&M. 